\title{
Implementation of Blended Learning Models to Improve Student Learning Outcomes in Junior High School
}

Deni Darmawan ${ }^{*}$, , Siti Ahadiah Nurjanah ${ }^{2}$, Ahmad Solihin $^{2}$, Asep Hidayat $^{2}$, Linda Setiawati $^{3}$

${ }^{1}$ Educational Technology Department, Faculty of Education, Universitas Pendidikan Indonesia, 40154 Indonesia

${ }^{2}$ Magister of Educational Technology Department, Institut Pendidikan Indonesia, 44154 Indonesia

${ }^{3}$ Library and Information Science Department, Faculty of Education Universitas Pendidikan Indonesia, 40154 Indonesia

A R T I C L E I N F O

Article history:

Received: 13 September, 2020

Accepted: 07 March, 2021

Online: 17 March, 2021

Keywords:

Blended Learning

Learning Outcomes

Online Video Learning

A B S T R A C T
The purpose of this study is to determine the improvement of the competence of junior high
school students through the application of blended learning models. This is a Classroom
Action Research comprising of two cycles and two observations of student activities, with
the descriptive statistics used for data analysis. From the results of the learning process
during the two cycles, it was found that students who learned using blended learning models
obtained a better competency improvement in the second cycle. The results of the calculation
from the first cycle showed that the average competence of students tested in English
learning was 70.12 with an activity level of $65.5 \%$. Furthermore, in the second cycle, the
competence became 78.00 with an activity level of $70.23 \%$.

\section{Introduction}

According to March (2020), students tend to be less active in exploring their English knowledge. Therefore, several studies have predicted using the blended learning model in schools to improve student learning outcomes in English. This model enables students to learn by interacting with Websites, Videos, or Learning E-Modules. This process was carried out at Junior High School Leuwigoong, Garut Region.

The rapid development of technology, communication, and information, especially the internet, has increased the need for Indonesian teachers to use it as a positive tool to support learning quality. Similarly, through e-learning, learning services become more flexible and can be carried out anywhere, irrespective of the time [1]. One positive value of Internet technology is that it allows students to discuss and collaborate to solve classroom problems and outside the school [2].

The concept of blended learning is a mixture of learning patterns. Blended learning is a combination of face-to-face and online learning to increase students' level of knowledge and analytical skills [3].

\footnotetext{
${ }^{*}$ Corresponding Author: Deni Darmawan, Universitas Pendidikan Indonesia, Street of dr. Setiabudi, 229 Bandung, 40154, Phone +6222013163, Email: deni_darmawan@upi.edu
}

Several schools in Indonesia still use the traditional face-toface learning process, irrespective of the rapid growth in information and communication technology (ICT). Online learning makes it easy for students to explore the knowledge and information needed in education [4]. Therefore, based on this phenomenon, this research aims to research questions on using the blended learning model to improve students' English competence at Junior High School Leuwigoong, Garut Regency.

\section{Theoretical Review}

\subsection{Educational Technology}

The current change in education from traditional to media communication using digital technology has significantly increased students' knowledge and skills. According to several educational experts such as [5]-[9], the face to face educational process between the teacher and students have changed due to the development of digital technologies [10].

However, students and teachers still find it difficult to master the technology, and therefore, various educational institutions in Indonesia are still using the traditional learning method. Therefore, it is hoped that educational institutions develop a learning revolution that turns face-to-face learning into a digital-based learning model. Educational Technology is a procedure used to solve student learning problems. In practice, it requires the 
competence of teachers with technological literacy. Similarly, teachers need to possess the ability to carry out learning using various sources, such as textbooks, journals, magazines, newspapers, CD ROMs, videos, radio, television, websites, social media, blogs, etc [11]. Furthermore, online learning is achieved by developing applied research designed in the form of integration between technology, digital media logs, computer motherboards, and audio-video input-output connected to broadcast television programs via satellite captured by the TV. Toners are used to create media communication to monitor and obtain programming options with positive educational values and learning to provide e-Learning services to the community.

\subsection{Online Learning}

Online learning is a model that has been used to achieve knowledge by open universities in the United States and the United Kingdom since the mid-1960s. This process converts materials such as lectures and simulations into videotape forms, which are distributed using the internet, DVDs, and CDs, thereby making it easier for students and teachers to learn and explore knowledge [12]. However, students need to combine online and face-to-face learning, known as blended learning, to maximize knowledge. Research conducted by [13] stated that blended learning can improve student learning outcomes and increase their interest in education compared to using only online learning.

Online learning consists of media consisting of a controller which grants the user access. Meanwhile, offline media is not equipped with a controller because users do not need to be connected to the Internet network. Examples of offline materials are tutorials on CDs or media made through students' applications without connecting to the internet network [14]. According to Mayes and Marison in Jeffrey, many teachers are interested in online learning, while Bates and Sangra stated that online learning needs direct understanding to provide feedback between teachers and students [15].

Learning needs to be carried out by installing a healthy internet joint learning management system through effective technology in developing countries [16]. The purpose of the blended learning model is to obtain the best learning by revising the various advantages of each component of conventional methods and online features. Blended learning is carried out by combining online and face-to-face learning using print, audio, audiovisual, computer, and M-learning technologies (mobile learning). The blended learning method comprises of six things, namely face to face, independent learning, application, tutorial, collaboration, and evaluation. In more detail, the needs that can be freed from the blended learning process are (1) sending subject material through E-learning, in the form of files uploaded and downloaded by students, (2) procurement of quizzes with new methods, using timers, random questions, and automatic assessment, (3) giving online assignments, (4) ability to visualize students' grades online (5) discussion forums, (6) user-friendly displays, and (7) telecommunications technical sharing forums [17].

\subsection{Blended Learning}

Blended learning is the solution to online learning's weaknesses because it combines online, offline, and face-to-face learning processes. Students need to adopt the right learning outcomes to understand the essential competencies of vocabulary mastery to enhance their learning outcomes. This educational model combines classical teaching (face to face) with online instruction. In [18], the author stated that Blended Learning is a logical evolution in knowledge acquisition. It provides solutions to the challenges of tailoring learning and development to individual needs. Furthermore, blended learning is an opportunity to integrate innovative advancements and technology offered by online learning with the best interaction and participation from the traditional process. Blended learning provides more flexibility in terms of time, place, and variety than online and face-to-face methods. Blended Learning's application encourages students to understand the material better and be more active in participating in educational activities to enhance their knowledge. This learning also emphasizes students to learn independently by utilizing various sources. Learners naturally build knowledge, which is applicable in their daily lives [19].

\section{Research Method}

The classroom action research method adopted from the [20] models were used to carry out this research. This study consists of 2 cycles, where each comprises four activities, namely planning, action, observation, and reflection. Therefore, the research process is deductive to answer the problem statement, a concept or theory is used. Furthermore, the research design was developed into three stages in the learning process. The addition of this stage is carried out to examine whether the blended learning model's application has the ability to affect student learning outcomes at each location.

This research was carried out in the even semester of the 2019/2020 school year of Junior High School Leuwigoong in Garut region, west java. The research subject consists of all students of grade VII of junior high school as the research samples.

Data were collected through observation, test, and interview methods. Learning activities with this Blended Learning strategy tend to continue to the next cycle assuming the indicators have not been successfully achieved. Furthermore, the obtained data were analyzed using descriptive statistics.

\section{Result and Discussion}

Online learning is also called distance learning that enables teachers/lecturers students to acquire knowledge outside school/college irrespective of their location. In this process, the teacher gives a tutorial and provides assignments to students to assess the subject matter's source on the internet. Therefore, based on the results of the classroom action research carried out, the English competence of students of junior high schools Leuwigoong at Garut Region is improved, as shown in Figure 1. The picture shows student competency scores in quantity from the increase in the pre-test and post-test scores. From these results, the findings were further confirmed by interview data and observations from peer teachers.

Figure 1 shows an increase in the learning outcome achieved by students from the pre-test and post-test achievements. These findings indicate that teachers' role of mobile learning, both in the first and second cycles, positively impacts student competence. 


\section{Implementation of Blended Learning}

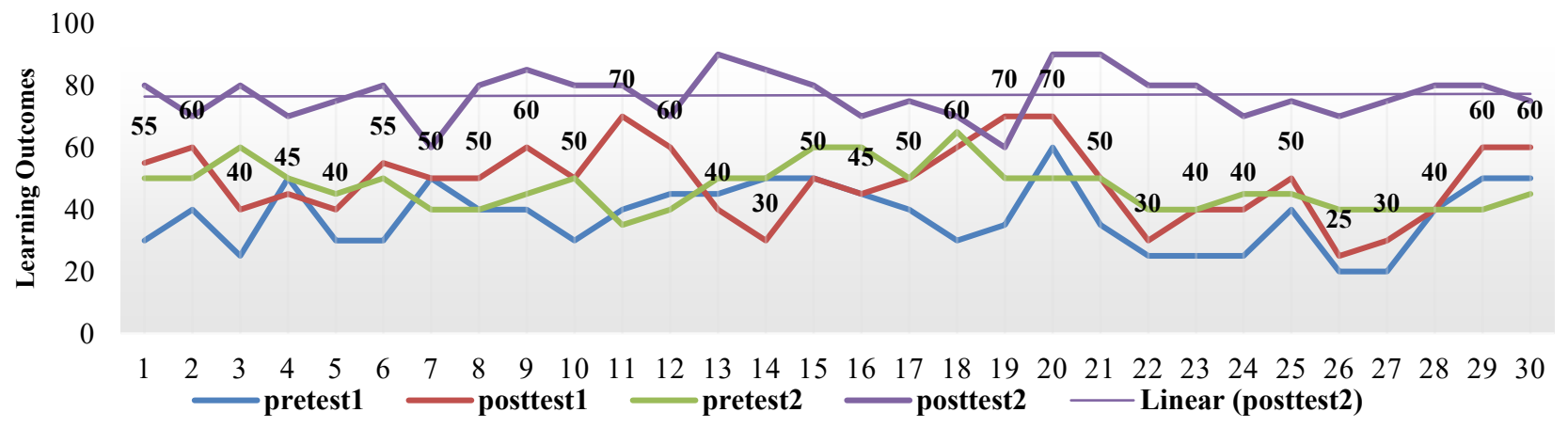

Figure 1: Implementation of Blended Learning

Therefore, the students' English competence was enhanced after the Figure 1 shows an increase in the learning outcome achieved by students from the pre-test and post-test achievements. These findings indicate that teachers' role of mobile learning, both in the first and second cycles, positively impacts student competence. Therefore, the students' English competence was enhanced after the implementation of two processes in the classroom. In [21], Blended learning combines face-to-face learning with the help of Information and Communication Technology ICT. Its advantages are as follows:

- Students interact directly with the content of learning.

- Enables users to interact with friends.

- Group discussions and exchange opinions,

- Access e-libraries, virtual classes.

- Online assessment.

- E-tuitions.

- Access and maintain learning blogs.

- Online seminars (webinars).

- Provide expert lecturers on youtube.

- Learn online via video and audio.

- Virtual laboratory.

Blended learning combines various educational tools such as real-time software, online web-based programs, and other applications not supporting the learning environment and knowledge management systems[22]. Blended learning combines online, face-to-face, and it is independently guided by mentors, teachers, or lecturers with structured education and its description.

Learning in this study is appropriate to support the curriculum and strategies in line with students' characteristics. Innovative work consists of teaching materials and the learning media that value innovation in schools. Teachers are expected to professionally use innovative work in learning to provide creative works obtainable from sources.

Such as the internet and store school supplies. The teacher also creates innovative work, which acts as a point and one of the requirements that need to be utilized.

This increase was due to the contribution of the use of Blended Learning in acquiring knowledge in English. This finding is in line with [23] research on how teachers teach in a balanced way, as reinforced by [24], which confirms that most teachers used well-developed engagement strategies in classrooms compared to online.

\section{Conclusion}

In conclusion, the learning process used in this research was carried out using a video-based online blended learning process to introduce the material and assignments. The study results in the first cycle showed that the average score for the observation sheet of students' learning creativity is $65.5 \%$ and in the high category. By the end of the second cycle, the use of online learning video is still performed, with a percentage of $70.23 \%$ in the very high category. This shows that the Blended Learning Model positively influences student learning outcomes with an increase from cycle I to cycle II. The average value of daily tests led to 70.12 and 78.00 in the first and second cycles, respectively. There is an average value of daily difficulties and minimum completeness criteria in English subjects, especially in the essential competencies of vocabulary improvement.

Blended learning-based online learning videos are teaching materials used by teachers and students to acquire knowledge. Online learning videos are rated by teachers as interactive teaching materials because they contain text, images, videos, animations, interactive quizzes, and other interactive features that attract students' attention. It is also considered efficient by the teacher because it is easy for students to learn. Teachers are also interested in making and using online learning videos in education with enthusiasm to help students.

\section{Conflict of Interest}

The authors declare no conflict of interest.

\section{Acknowledgment}

The authors are grateful to the Department of Educational Technology at the Indonesian Institute of Education, Garut, and the Head of the Education Office for supporting this study.

\section{Reference}

[1] C.H. Hwang, G. J., \& Chen, "Influences of an inquiry based ubiquitous gaming design on students' learning achievements, motivation, behavioral patterns, and tendency towards critical thinking and problemsolving. British Journal of Educational Technology,” 信阳师范学院, 1(1), 287-295, 2017, doi:10.1016/j.sbspro.2015.04.758.

[2] Z. Halili, S. H., Razak, R. A., \& Zainuddin, "Exploring the use of 'Wiggio'to 
support online collaborative learning for adult learners. In Economics, Social Sciences and Information Management: Proceedings of the 2015 International Congress on Economics, Social Sciences and Information Management (IC," Biomass Chem Eng, 49(23-6), 23-34, 2015.

[3] J.M. Carmen, Blended Learning Design: Five Key Ingredients, http://www.agilantlearning.com, 2018.

[4] B. Tom, "Teaching methods for learning outcomes," Education + Training, 39(9), 344-348, 1997, doi:10.1108/00400919710192377.

[5] K. Hovland, Carl I., Irving K. Janis, and Harold H., "Communication and Persuasion," New Haven, CT: Yale University Press., 1953.

[6] J. Farr, J.S. Hacker, N. Kazee, "The policy scientist of democracy: The discipline of Harold D. Lasswell," American Political Science Review, 100(4), 579-587, 2006, doi:10.1017/S0003055406062459.

[7] R. Eldeeb, "Review and Critique of the book 'Education and Experience' by John Dewey," IOSR Journal of Research \& Method in Education (IOSRJRME), 1(2), 44-47, 2013, doi:10.9790/7388-0124447.

[8] S. Littlejohn, Theories of human communication, 10th ed., Waveland.Inc, 2011.

[9] O.U. Effendy, "Ilmu Komunikasi. Teori dan Praktek," Rosda Karya, 2011.

[10] D. dermawan. . Ishak Abdulhak, Teknologi pendidikan.

[11] M. Simonson, "Educational Technology Review of the Field by Michael Simonson Instructional Technology and Distance Education," Educause Center for Applied Research, (January 2003), 2016.

[12] E.C. Bruce Joyce, Marsha Weil, Model of Teaching, Pustaka Pelajar., Yogyakarta, 2008.

[13] P.D.M. Charles D. Dziuban, Joel L. Hartman, "Blended learning. Research Bulletin.," 7(1), 2004, 2004.

[14] A. Waleed, Z. Essam, "Blending QR code with video learning in the pedagogical process for the college foundation level," Interactive Technology and Smart Education, 17(1), 67-85, 2019, doi:10.1108/ITSE08-2019-0043.

[15] S.J. Ajeffrey, L.M. Milne, J, "Blended Learning: How Teachers Balance the Blend of Online and Classroom Components, Journal of Information Technology Education," 13, 2014, 2014.

[16] E. Kintu, M. J., Zhu, C., and Kagambe, "Blended Learning Effectiveness: The Relationship between Student Characteristics, Design Features and Outcomes. International Journal of Educational Technology in Higher Education,” 信 阳 师 范学 院， 1(1), 287-295, 2017, doi:10.1016/j.sbspro.2015.04.758.

[17] R. KUPETZ, B. ZIEGENMEYER, "Blended learning in a teacher training course: Integrated interactive e-learning and contact learning," ReCALL, 17(2), 179-196, 2005, doi:10.1017/S0958344005000327.

[18] K. Thorne, Blended learning: How to integrate online and traditional learning. London:, Kogan Page Publishers., London, 2003.

[19] C. Chaudron, Learning outcomes, Cambridge University Press: 154-179, 1988, doi:10.1017/CBO9781139524469.008.

[20] R. Kemmis, S. \& Mc.Taggart, "The Action Research Planner.," Victoria: DeakinUniversity Press., 1988.

[21] K.L. Lalima, "Blanded learning: an Inovative Approach. Universal Journal Of Educational Reserch.,”信阳师范学院，1(1), 287-295, 2017, doi:10.1016/j.sbspro.2015.04.758

[22] D. Darmawan, E. Suryadi, D. Wahyudin, "Smart Digital for Mobile Communication Through TVUPI Streaming for Higher Education," International Journal of Interactive Mobile Technologies (IJIM), 13(05), 30, 2019, doi:10.3991/ijim.v13i05.10286.

[23] E.K. Swart, T.M.J. Nielen, M.T. Sikkema, D. Jong, "Supporting learning from text : A meta-analysis on the timing and content of effective feedback," Educational Research Review, 28(April), 100296, 2019, doi:10.1016/j.edurev.2019.100296.

[24] L.M. Jeffrey, J. Milne, G. Suddaby, A. Higgins, "Blended Learning: How Teachers Balance the Blend of Online and Classroom Components," 13, 121-140, 2014. 